\title{
PENGARUH PERLAKUAN DAUN DAN SUHU TERHADAP WAKTU DISTILASI PADA ISOLASI MINYAK CENGKEH MENGGUNAKAN SUPER-STEAM DISTILLATION
}

\author{
Sutijan*, Arief Budiman, dan Arie Yohanes \\ Process System Engineering Research Group \\ Jurusan Teknik Kimia, Fakultas Teknik, Universitas Gajah Mada \\ Jalan Grafika 2 Yogyakarta \\ Email: sutijan@chemeng.ugm.ac.id
}

\begin{abstract}
Abstrak
Minyak cengkeh umumnya diproduksi oleh para petani dari daun cengkeh dengan metode steam distillation. Parameter yang paling berpengaruh pada biaya distilasi adalah waktu distilasi, karena waktu distilasi akan berbanding lurus dengan biaya bahan bakar. Penelitian ini bertujuan untuk mempelajari pemakaian super-steam distillation dimana uap air jenuh yang digunakan untuk mendistilasi minyak cengkeh bersuhu lebih tinggi dari titik didih normal air $\left(100^{\circ} \mathrm{C}\right)$. Uap jenuh bersuhu tinggi dapat diperoleh dengan mendidihkan campuran air dan gliserol atau pelarut lainnya yang bertitik didih tinggi dan larut sempurna dalam air. Pemakaian uap jenuh bersuhu tinggi akan meningkatkan difusitivitas efektif minyak cengkeh dalam jaringan sel tumbuhan, sehingga akan mempercepat waktu distilasi. Pada penelitian ini digunakan variasi konsentrasi gliserol 0, 10, 25, 50 dan 75\% volume. Selain itu juga dipelajari pengaruh pencacahan daun cengkeh sebelum didistilasi. Hasil penelitian menunjukkan bahwa super-steam distillation dengan campuran gliserol dan air dengan perbandingan volum 10-75\% mampu memperpendek waktu distilasi sebesar 46$72 \%$. Besarnya nilai koefisien transfer massa dan diffusivitas efektif rerata untuk daun cengkeh tanpa perlakuan adalah $2 \times 10^{-4}$ detik $^{-1}$ dan $3,6 \times 10^{-4} \mathrm{~m}^{2} /$ detik, sedangkan untuk daun dengan pencacahan adalah $8,3 \times 10^{-3}$ detik $^{-1}$ dan $5,8 \times 10^{-4} \mathrm{~m}^{2} /$ detik.
\end{abstract}

Kata Kunci: Isolasi, Minyak Cengkeh, Super-Steam Distillation, Gliserol

\begin{abstract}
Clove oil was generally obtained from clove leaves by using steam distillation. Distillation time was the most important factors in steam distillation as it was proportional to energy cost. In this work, the use of high boiling compound to accelerate steam distillation was studied in which steam distillation was conducted using temperature greater than $100^{\circ} \mathrm{C}$. High temperature saturated steam could be obtained by boiling glycerol-water mixture. Glycerol was selected due to its properties in which it was completely water-soluble and high boiling compound. High temperature increased mass transfer of oil in the water within cell tissue of clove leaves, and hence shortened the distillation time. In this work, glycerol concentrations of $0,10,25,50$ and $75 \%$ by volume were used. The treatment of clove leaves was also investigated. The results showed that glycerol concentration of $10-75 \%$ by volum resulted in distillation time reduction of $46-72 \%$ compared to conventional steam distillation. For natural clove leaves without treatment, the convective mass transfer coefficient and effective molecular diffusivity were obtained to be $2 \times 10^{-4}$ second $^{-1}$ and $3,6 \times 10^{-4} \mathrm{~m}^{2} /$ second, whereas for chopped leaves these were $8,3 \times 10^{-3}$ second $^{-1}$ and $5,8 \times 10^{-4}$ $\mathrm{m}^{2} /$ second, respectively.
\end{abstract}

Keywords: Isolation, Clove Oil, Super-Steam Distillation, Glycerol

*korespondensi 


\section{Pendahuluan}

Minyak atsiri merupakan salah satu produk kimia yang memiliki nilai ekonomis yang tinggi. Penggunaannya selain untuk campuran parfum, beberapa minyak atsiri digunakan untuk berbagai macam keperluan seperti dalam industri kosmetik, farmasi dan kesehatan, dan lain-lain. Pengambilan minyak atsiri dapat dilakukan dengan alat-alat yang sederhana dan metode yang mudah dilakukan dengan biaya investasi yang relatif murah sehingga dapat memberikan keuntungan ekonomi yang cukup tinggi.

Saat ini banyak sekali bermunculan industri-industri penyulingan minyak atsiri yang menggunakan teknologi distilasi baik yang untuk skala besar maupun skala kecil di Indonesia. Industri-industri ini jumlahnya didominasi oleh industri-industri skala rakyat yang menggunakan teknologi distilasi (Fatoni, 2005; Hakiki, 2007; Nugraha, 2008; Yusnadi, 2008). Industri skala rakyat ini biasanya memerlukan waktu distilasi yang cukup lama. Waktu yang lama ini mengakibatkan konsumsi energi untuk distilasi menjadi sangat besar yang mengakibatkan keuntungan penyuling menjadi berkurang.

Usaha-usaha untuk memperbaiki unjuk kerja distilasi uap telah dilakukan. Hakiki (2007) menggunakan boiler berpenghalang untuk memperpanjang waktu kontak uap dengan daun cengkeh. Adanya waktu kontak yang lebih baik terbukti mampu mengurangi waktu distilasi yang cukup signifikan. Yusnadi (2008) mempelajari pengaruh kenaikan tekanan terhadap pengurangan waktu distilasi. Metode-metode di atas, meskipun terbukti dapat mengurangi waktu distilasi hingga $\quad 45 \%$ dibandingkan distilasi konvensional, tetapi menyebabkan tingkat kesulitan yang lebih tinggi di dalam pengoperasian distilasi uap. Pemasangan penghalang (baffle) dalam ketel akan menyebabkan kesulitan ketika memasukkan dan mengeluarkan daun cengkeh. Penggunaan tekanan untuk menaikkan titik didih air menyebabkan kenaikan biaya alat karena harus menggunakan peralatan yang lebih tebal agar tahan terhadap tekanan.

Salah satu cara mempercepat waktu distilasi adalah dengan cara mempercepat proses perpindahan massa minyak dari dalam daun ke separating agent (steam). Kecepatan distilasi minyak atsiri pada umumnya dikontrol oleh kecepatan difusi molekul minyak atsiri di dalam air di dalam jaringan sel daun atau ranting suatu bahan. Salah satu cara untuk mempercepat kecepatan transfer massa secara difusi adalah dengan meningkatkan suhu sistem (biasanya dengan uap air). Suhu steam dapat dinaikkan dengan cara memanfaatkan hubungan tekanan uap suatu larutan terhadap titik didihnya. Distilasi dengan menggunakan steam dengan suhu yang tinggi pada tekanan atmosferis disebut Super Steam Distillation. Pada penelitian ini, uap jenuh bersuhu tinggi diperoleh dengan cara menguapkan campuran air-gliserol.

Penelitian ini bertujuan untuk mempelajari pengaruh penambahan gliserin terhadap kecepatan distilasi minyak atsiri serta memperoleh parameter-parameter kecepatan transfer massa yang dapat digunakan pada perancangan alat yang sebenarnya.

\section{Steam Distillation}

Distilasi merupakan pemisahan komponen-komponen dalam satu larutan berdasarkan distribusi substansi-substansi pada fase gas dan fase cair dengan menggunakan perbedaan volatilitas dari komponen-komponennya yang cukup besar. Transfer massa minyak dari dalam butiran padatan ke solvent meliputi dua proses seri, yakni difusi dari dalam padatan ke permukaan butiran dan transfer massa dari permukaan padatan ke solven. Jika salah satu proses berlangsung lebih cepat, maka kecepatan perpindahan massa dikontrol oleh proses yang lebih lambat. Akan tetapi, jika proses berlangsung dengan kecepatan yang tidak jauh berbeda, maka kecepatan perpindahan massa dipengaruhi oleh keduanya.

Kecepatan difusi ini dipengaruhi oleh beberapa faktor, antara lain susunan bahan dalam ketel, suhu dan tekanan uap, berat jenis dan kadar air dari bahan, serta berat molekul dari komponen kimia dalam minyak.

Difusi solut di dalam daun menuju ke permukaan bahan merupakan suatu fungsi dari suhu uap. Makin tinggi suhu uap, maka makin tinggi kecepatan difusinya, sehingga dapat diharapkan kecepatan distilasi akan semakin cepat.

\section{Kesetimbangan uap-cair biner}

Pada suatu campuran biner dimana salah satu komponennya lebih volatile, maka titik didih larutan tersebut akan tercapai pada saat jumlah tekanan parsial kedua komponen tersebut sama dengan tekanan atmosfer. Dari 
hubungan ini dapat dilihat bahwa komposisi cairan dalam suatu larutan akan mempengaruhi titik didih larutan.

Berdasarkan hal diatas, maka bila gliserol yang memiliki titik didih $287,85^{\circ} \mathrm{C}$ ditambahkan ke dalam air dengan komposisi tertentu maka titik didih air akan meningkat (berada di antara $100-287,85^{\circ} \mathrm{C}$ ) yang berakibat pada suhu steam jenuh yang dihasilkan meningkat pula.

\section{Penyusunan Model Matematik}

Untuk evaluasi nilai parameterparameter perpindahan massa, perlu disusun suatu model matematika yang dapat menggambarkan fenomena yang terjadi pada proses distilasi uap.

Operasi distilasi uap yang merupakan fenomena transfer massa padatan - gas, dapat dilakukan dengan menyusun butiran padatan dalam kolom fixed bed. Solven berupa uap air jenuh dialirkan secara kontinu di antara butiran padatan. Oleh karena padatan disusun dalam kolom fixed bed, maka koefisien transfer massanya lebih mudah dinyatakan dalam bentuk koefisien transfer massa volumetrik.

Pada penyusunan model matematik diambil beberapa asumsi, yaitu ukuran padatan seragam, butiran padatan terdistribusi merata dalam kolom, aliran solven mengikuti pola aliran plug flow, perpindahan massa hanya berlangsung aksial, isotermal serta rapat massa solven dianggap tetap karena kadar minyak dalam solven kecil.

Pemodelan peristiwa distilasi yang terjadi pada kolom fixed bed, ditinjau dari elemen volume tumpukan padatan dinyatakan sebagai berikut:

$$
\begin{gathered}
\mathfrak{D}_{e} \cdot \frac{\delta^{2} C_{A}}{\delta z^{2}}-\frac{G}{\rho_{s}} \cdot \frac{\delta C_{A}}{\delta z}+k c a \cdot\left(C_{A}^{*}-C_{A}\right) \\
=\varepsilon \cdot \frac{\delta C_{A}}{\delta t} \\
-\frac{k c a \cdot \rho_{s} \cdot\left(C_{A}^{*}-C_{A}\right)}{\rho_{s}}=\frac{\delta X_{A}}{\delta t}(2)
\end{gathered}
$$

dengan kondisi batas:

$$
\begin{gathered}
t=0 ; \mathrm{z}=\mathrm{z} ; C_{A}=C_{A 0} ; X_{A}=X_{A 0} \\
\quad t=0 ; \mathrm{z}=\mathrm{z} ; C_{A}=C_{A 0} \\
t=0 ; \mathrm{z}=\mathrm{L} ; C_{A}=C_{A 0 u t}
\end{gathered}
$$

Nilai parameter transfer massa De dan $\mathrm{k}_{\mathrm{c}} \mathrm{a}$ dievaluasi dengan meminimumkan nilai kuadrat dari beda nilai antara percobaan dan simulasi. Penyelesaian dilakukan dengan bantuan program komputer Matlab 7.1.

\section{Metodologi}

Bahan yang digunakan adalah daun cengkeh kasar yang diperoleh dari Pasar Kranggan, Yogyakarta. Daun cengkeh kasar yang dipergunakan, dipersiapkan dengan dua cara yang berbeda, yakni dicacah dan tidak dicacah. Gliserin untuk larutan pembangkit uap diperoleh dari Jurusan Teknik Kimia UGM dan dari CV General Labora. Larutan gliserin yang dipergunakan adalah larutan gliserin dalam air dengan konsentrasi yang bervariasi yakni $0 \%$ v, 10\%v, 25\%v, dan $75 \%$ v.

Daun cengkeh kasar diletakkan dalam tabung kaca berdiameter $5 \mathrm{~cm}$ dan panjang 43 $\mathrm{cm}$. Uap dihasilkan dari labu leher tiga berkapasitas 1L. Selama percobaan, suhu di dalam labu leher tiga dipertahankan pada suhu didih larutan pembangkit uap dengan cara menjaga tekanan pada kondisi atmosferik dan konsentrasi larutan di dalam labu leher tiga dengan air make-up yang disuplai dari corong pemisah.

Pengamatan dilakukan terhadap volume minyak yang tertampung di dalam buret pemisah dan terhadap suhu didih larutan gliserin. Pengamatan dimulai ketika tetesan embunan dari uap telah terjadi di condenser hingga waktu 120 menit dengan interval waktu setiap 10 menit.

\section{Hasil dan Pembahasan}

Untuk tiap-tiap data percobaan yang dilaksanakan dalam penelitian ini, diperoleh data jumlah minyak yang didapat secara akumulatif. Data-data tersebut diklasifikasikan menjadi dua, yakni data untuk percobaan untuk daun dengan perlakuan dicacah dan tanpa perlakuan apapun. Dari tiap klasifikasi data tersebut diklasifikasikan kembali menjadi empat, yakni untuk data tiap konsentrasi (\%volum) umpan boiler. Hasil percobaan dan simulasi berupa massa tertampung setiap saat yang dinyatakan dalam \% recovery disajikan dalam Gambar 1 dan 2.

Dari Gambar 1 dan 2 dapat terlihat bahwa pada konsentrasi gliserol yang semakin tinggi, waktu distilasi (yakni sampai waktu dimana terjadi berat minyak konstan) semakin cepat. Hal ini disebabkan karena pada konsentrasi gliserin yang semakin tinggi, titik didih larutan pembangkit uap semakin tinggi, sehingga suhu uap jenuh yang 
berfungsi sebagai solven juga semakin tinggi sebagaimana disajikan pada Tabel 1 . Hal ini akan mengakibatkan difusi efektif dalam sel dan jaringan daun meningkat, sehingga minyak lebih cepat terambil dari dalam daun. Hal ini juga mengindikasikan bahwa pada peristiwa pengambilan minyak daun cengkeh dengan menggunakan distilasi uap, langkah yang mengontrol adalah difusi molekul minyak dalam jaringan sel bahan, bukan perpindahan konveksi dari permukaan bahan ke badan gas.

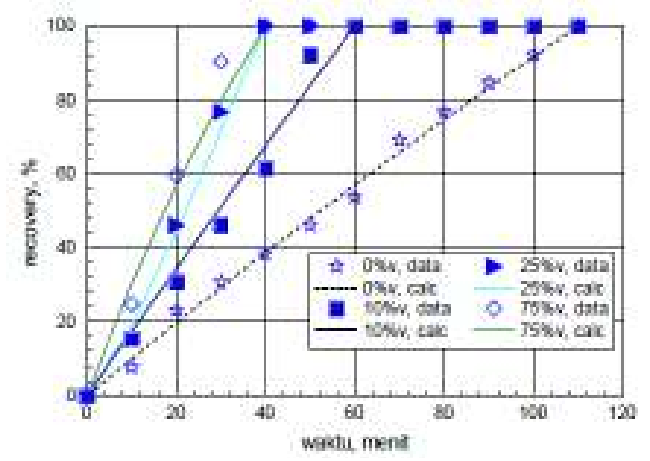

Gambar 1. Hubungan antara persen recovery dengan waktu distilasi pada pada berbagai konsentrasi gliserin untuk daun cengkeh tidak dicacah.

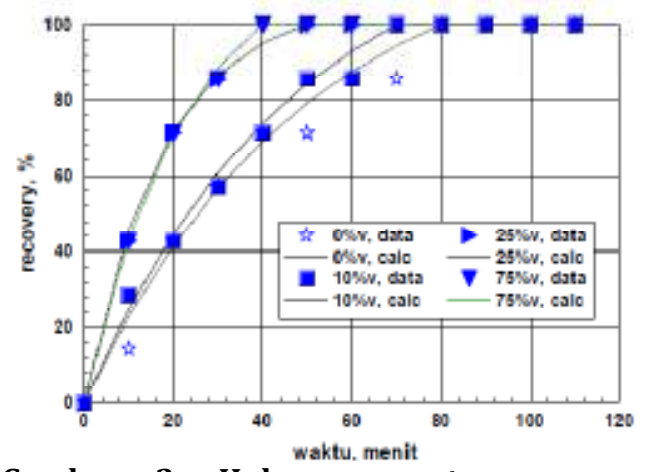

Gambar 2. Hubungan antara persen recovery dengan waktu distilasi pada pada berbagai konsentrasi gliserin untuk daun cengkeh yang dicacah.

Dengan adanya penambahan gliserin dalam boiler, distilasi uap dapat dipercepat secara signifikan. Penambahan gliserin ini akan mengurangi waktu yang digunakan untuk distilasi sebagaimana tersaji dalam Gambar 1 dan 2. Pengurangan waktu distilasi akan berbanding lurus dengan konsumsi energi untuk pembangkitan steam dan sekaligus dengan biaya operasi. Besarnya penghematan waktu yang dapat dicapai dengan penambahan gliserin sebanyak $10 \%$ $\mathrm{v}$ adalah $46,5 \%$, untuk penambahan $25 \%$-v adalah $65,1 \%$, dan untuk penambahan $75 \%$-v adalah $72,0 \%$.

Untuk setiap data percobaan, dihitung koefisien transfer massa volumetrik (kca) dan difusivitas efektif (De) dengan cara optimasi. Harga-harga konstanta tersebut diperoleh dengan bantuan program komputer. Hasil perhitungan dapat dilihat pada Tabel 1 .

Tabel 1. Harga konstanta-konstanta perpindahan massa untuk berbagai variasi percobaan.

\begin{tabular}{|c|c|c|c|c|}
\hline Daun & $\begin{array}{c}\text { Suhu, } \\
\text { oC }\end{array}$ & $\% v$ & $\begin{array}{c}\text { De, } \\
\left(\mathrm{m}^{2} / \mathrm{dtk}\right)\end{array}$ & $\begin{array}{c}\text { kca, } \\
(1 / \text { dtk })\end{array}$ \\
\hline \multirow{4}{*}{ 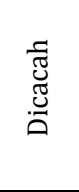 } & 100 & 0 & $8,76 \times 10^{-4}$ & $0,80 \times 10^{-4}$ \\
\hline & 102 & 10 & $10,03 \times 10^{-4}$ & $1,70 \times 10^{-4}$ \\
\hline & 104 & 25 & $5,09 \times 10^{-4}$ & $0,38 \times 10^{-4}$ \\
\hline & 108 & 75 & $5,84 \times 10^{-4}$ & $83,43 \times 10^{-4}$ \\
\hline & ata-rata & & $7,43 \times 10^{-4}$ & $2,16 \times 10^{-4}$ \\
\hline \multirow{4}{*}{ 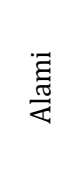 } & 100 & 0 & $3,74 \times 10^{-4}$ & $1,45 \times 10^{-4}$ \\
\hline & 102 & 10 & $4,26 \times 10^{-4}$ & $1,43 \times 10^{-4}$ \\
\hline & 104 & 25 & $1,92 \times 10^{-4}$ & $2,98 \times 10^{-4}$ \\
\hline & 108 & 75 & $4,68 \times 10^{-4}$ & $2,15 \times 10^{-4}$ \\
\hline \multicolumn{3}{|c|}{ Rata-rata } & $3,65 \times 10^{-4}$ & $2,00 \times 10^{-4}$ \\
\hline
\end{tabular}

Dari hasil perhitungan seperti pada Tabel 1, dapat terlihat bahwa nilai-nilai kca untuk kedua jenis bahan relatif sama, sedangkan nilai De dari bahan dicacah teramati lebih tinggi dibanding bahan alami. Jika ditinjau dari kecepatan difusi minyak atsiri dalam air saja (dalam jaringan sel daun), pada suhu yang sama, kecepatan difusinya juga akan sama. Tetapi untuk daun dicacah, karena ukuran bahan menjadi jauh lebih pendek, waktu yang diperlukan oleh molekul minyak untuk mencapai permukaan bahan menjadi lebih singkat. Hal ini akan mengakibatkan kecepatan teramatinya menjadi lebih besar.

\section{Kesimpulan}

Dari penelitian yang dilakukan, disimpulkan bahwa distilasi uap untuk mengambil minyak cengkeh dapat dipercepat dengan cara menggunakan uap jenuh bersuhu tinggi. Uap jenuh bersuhu tinggi dapat diperoleh dengan cara menambahkan solven bertitik didih tinggi seperti gliserin. Penambahan gliserin sebanyak $10 \% \mathrm{v}-75 \% \mathrm{v}$ 
mampu menghemat waktu distilasi sebanyak $46-72 \%$, yang berarti pula penghematan energi dan biaya operasi.

\begin{tabular}{|c|c|}
\hline \multicolumn{2}{|c|}{ Daftar Notasi } \\
\hline $\mathrm{CA}_{\mathrm{A}}, \mathrm{CA}_{\mathrm{A}}{ }^{*}$ & $\begin{array}{l}\text { fraksi massa minyak dalam } \\
\text { solven, fraksi massa dalam } \\
\text { kesetimbangan dengan padatan } \\
\text { (gram minyak/gram solven) }\end{array}$ \\
\hline De & $\begin{array}{l}\text { konstanta difusivitas efektif } \\
\left(\mathrm{cm}^{2} / \text { menit }\right)\end{array}$ \\
\hline G & $\begin{array}{l}\text { mass flow rate (gram } \\
\text { solven } / \mathrm{cm}^{2} \text {.menit) }\end{array}$ \\
\hline $\mathrm{H}$ & konstanta Henry \\
\hline $\mathrm{kca}$ & $\begin{array}{l}\text { konstanta perpindahan massa } \\
(1 / \text { menit })\end{array}$ \\
\hline $\mathrm{t}$ & waktu (menit) \\
\hline $\mathrm{X}_{\mathrm{A}}$ & $\begin{array}{l}\text { fraksi massa minyak dalam } \\
\text { padatan (gram minyak/gram } \\
\text { padatan) }\end{array}$ \\
\hline $\mathrm{z}$ & panjang kolom (cm) \\
\hline$\varepsilon$ & void fraction \\
\hline$\rho s$ & massa jenis solven $\left(\mathrm{gram} / \mathrm{cm}^{3}\right)$ \\
\hline$\rho$ в & rapat massa bulk (gram/ $\left.\mathrm{cm}^{3}\right)$ \\
\hline
\end{tabular}

\section{Daftar Pustaka}

Fatoni, A., Pengambilan Minyak Atsiri Kayu Manis Dengan Distilasi Uap, Laporan Penelitian, Laboratorium Teknik Kimia Umum, Jurusan Teknik Kimia, UGM, 2005, Yogyakarta.

Hakiki, M. N., Pengaruh Penambahan Baffle terhadap Waktu Distilasi pada Pengambilan Minyak dari Daun Cengkeh, Laporan Penelitian, Laboratorium Operasi Teknik Kimia, Jurusan Teknik Kimia, UGM, 2007, Yogyakarta.

Nugraha, K. A., Pemodelan Distilasi Uap Untuk Pengambilan Minyak Atsiri Dari Beberapa Jenis Daun, Laporan Penelitian, Laboratorium Proses Pemisahan, Jurusan Teknik Kimia, UGM, 2008, Yogyakarta.

Yusnadi, Pengaruh Kondisi Operasi terhadap Waktu Distilasi Pada Pengambilan Minyak Atsiri Dari Daun Cengkeh, Laporan Penelitian, Laboratorium Proses Pemisahan, Jurusan Teknik Kimia, UGM, 2008, Yogyakarta. 